\title{
The utility of endovaginal sonography in the evaluation of fecal incontinence
}

\author{
J. M. Ramírez, V. Aguilella, M. Martínez and J. A. Gracia \\ Unit of Coloproctology. Service of Surgery B. Hospital Clínico Universitario. Zaragoza, Spain
}

\begin{abstract}
Objective: the endoanal sonography in female patients with faecal incontinence is sometimes difficult and can lead to diagnostic errors. The aim of this study is to evaluate the value of endovaginal sonography in such cases.

Material and method: thirty female patients complaining of faecal incontinence are included in the study. Anal endosonography was performed in all of them in a single ambulatory session, pictures were taken from all along the anal and results were analyzed afterward. Vaginal endosonography was then perfomed using the same equipment. Result from both techniques were compared.

Results: endoanal sonography was performed in all $30 \mathrm{pa}-$ tients. In 17 cases no anomalies were found. In 3 patients a simple internal anal sphincter defect was found. One case showed a lateral lesion in both sphincters. Six cases presented anterior external defect and in the rest 3 cases a clear view of the anterior wall was imposible. Vaginal endosonography shows a clear image of the anal canal in 23 out of 30 patients. In two cases changed the results of anal endosonography.

Conclusion: in the study of faecal incontinence, despite of its technical limitations, endovaginal ulltrasound could be of help when the anterior wall of the anal canal is not properly defined.
\end{abstract}

Key words: Sonography. Endoanal sonography. Vaginal sonography. Faecal incontinence.

Ramírez JM, Aguilella V, Martínez M, Gracia JA. The utility of endovaginal sonography in the evaluation of fecal incontinence. Rev Esp Enferm Dig 2005; 97: 317-322.

Recibido: 28-09-04.

Aceptado: 22-12-04.

Correspondencia: José Manuel Ramírez Rodríguez. Sección de Coloproctología. Servicio de Cirugía B. Hospital Clínico Universitario. C/ San Juan Bosco, 15. 50009 Zaragoza. Telf.: 976556 400. e-mail: jramirez@unizar.es

\section{INTRODUCTION}

During the last decade, endoanal ultrasonography has become a very helpful tool not only in the study of rectal tumors $(1,2)$ but also as a diagnostic complementary aid for benign anal disease $(3,4)$, mainly in patients with fecal incontinence and fistula. In fact, nowadays endoanal ultrasound, which is an easy-to-perform and well-tolerated technique, is considered an indispensable means for evaluating the anatomy of the anal canal and has replaced other, more uncomfortable techniques (5).

Nevertheless, on occasion, ultrasound scans of the high and medium anterior anal canal in women cannot obtain good images, mainly due to normal variants of the female anatomy, which could be erroneously confused with an anal defect (6). In this regard, endovaginal ultrasound has been proposed (7) as a complementary tool for the study of fecal incontinence in females. The aim of this study was to evaluate the actual value of endovaginal sonography in female patients complaining of fecal incontinence and to compare it with the worldwide accepted endoanal ultrasound technique.

\section{MATERIAL AND METHOD}

Thirty patients (mean age 52 years, range $24-76$ years) seen in our outpatient clinic due to fecal incontinence are included in the study. Of these 30 patients, 23 reported vaginal deliveries ( 3 of which had sepsis from episiotomy wounds); 4 out of 30 patients had a previous surgery in the anal area (three cases of hemorrhoidectomy and one fistulectomy); the other three patients complained of rectal prolapse.

After being carefully informed about the ultrasound examination, an ambulatory anal endosonography was performed in all of them using the equipment and technique previously described (3). The study was started in 
the high anal canal at the level of the puborectalis muscle, and slowly proceeded up to the anal margin. All the anal canal structures were sequentially pictured and recorded in our prospective database. Once the endoanal test had been completed, the probe condom was changed and the endovaginal study was performed following the technique and normal patterns described by Poen et al. (8) (Fig. 1). We deemed the study satisfactory when the anal canal could be fully imaged.

According to our aim, vaginal endosonography was assumed to be of real value when information collected changed therapy options or if images obtained were of a much better quality.

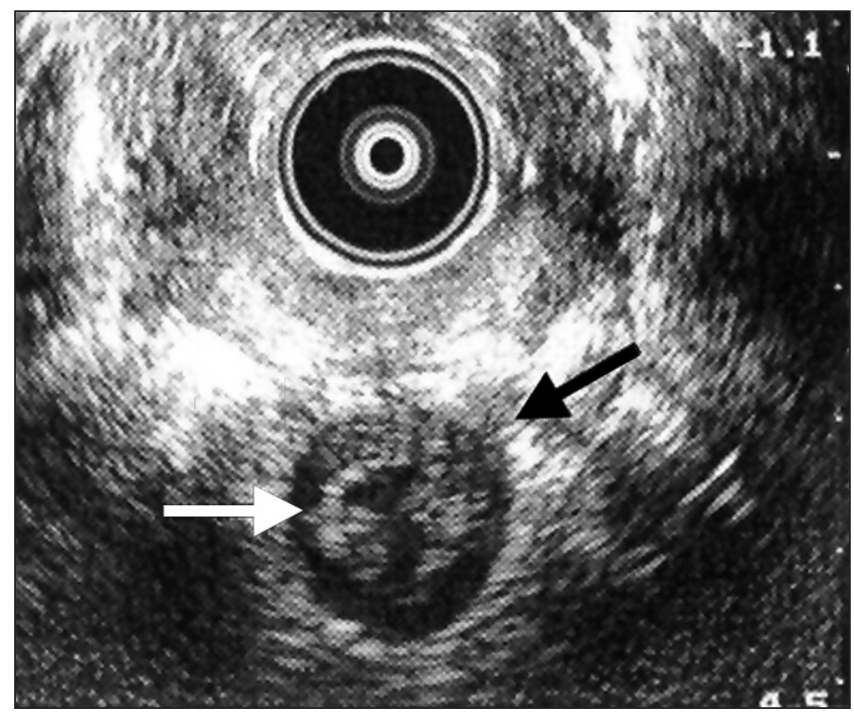

Fig. 1.- Normal endovaginal ultrasound. It is possible to identify the external (black arrow) as well as the internal (white arrow) anal sphincter. Ecografía endovaginal normal. Se aprecian el esfínter anal externo (flecha negra) y el interno (flecha blanca).

\section{RESULTS}

Anal endosonography was safely performed in all 30 patients. Mean duration, as measured from probe introduction to probe withdrawal, was 10 min (range 5-20).

Table I shows the results of the study. In 17 patients $(57 \%)$ the endoanal ultrasound test was satisfactory, with a complete view of all anal canal components and no abnormalities. Three out of 30 patients showed a defect of the internal anal sphincter in the mid anal canal, and in one patient (the one who had had a fistulectomy) a lateral internal and external sphincter defect was detected at the mid and lower levels. In 6 cases (30\%) anal endosonography suggested an anterior defect in the mid-high anal canal. In the other 3 patients, due to a very short anal canal and loose pelvic floor, the anterior anatomy could not be satisfactorily viewed; these three cases were labelled as "doubtful study" (Fig. 2).
Table I. Results from our serie of 30 patients

\begin{tabular}{lcccc}
\hline Endoanal ultrasound & \multicolumn{3}{c}{ Endovaginal ultrasound } \\
\hline & 3 & $1 *$ & 1 & 1 \\
\hline Doubtful study & 6 & 3 & 2 & 1 \\
Anterior defect & 3 & 1 & - & 2 \\
AlS defect & 1 & - & 1 & - \\
Lateral defect of & Insufficient & $\begin{array}{c}\text { Normal } \\
\text { study }\end{array}$ \\
IAS and EAS & 17 & - & 3 & 14 \\
Normal anal canal & 17 & 5 & 7 & 18 \\
Overall & 30 & &
\end{tabular}

IAS: internal anal sphincter. EAS: external anal sphincter; *: Anterior defect.

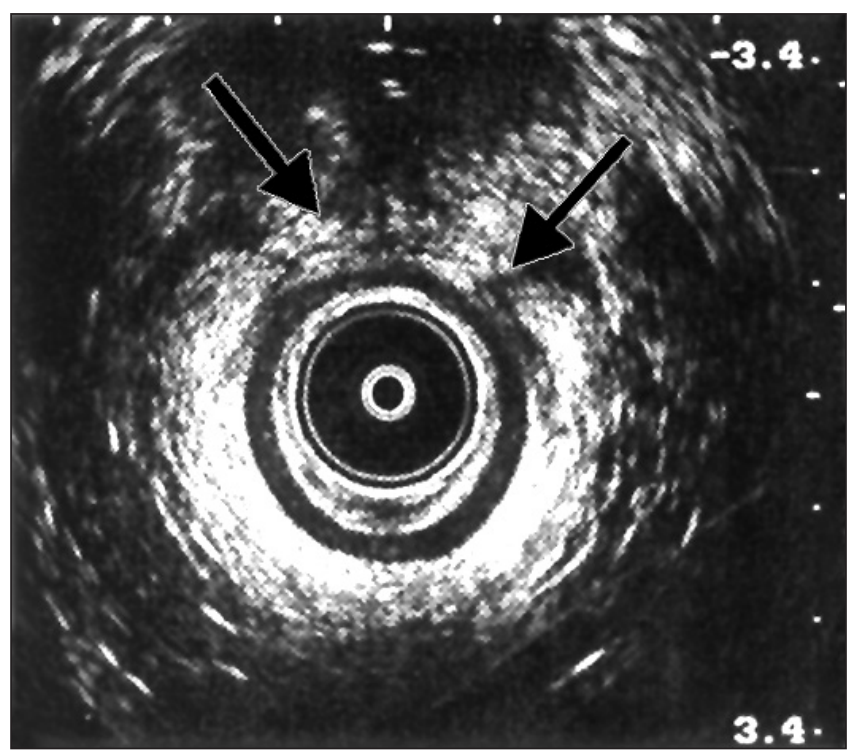

Fig. 2.- Endoanal ultrasound scan, mid anal canal. This looks like an anterior defect, as limited by the arrows.

Ecografía endoanal, canal anal medio. Parece existir un defecto de tabique anterior, delimitado por las flechas.

Regarding vaginal endosonography, mean duration was 15 min (range 5-25) and -as showed in table I- only 23 (76\%) of patients could be adequately studied. Eighteen out of 23 had a normal examination; one of these had been previously misdiagnosed with anterior defect using anal ultrasonography (Fig. 3). Another of these cases had been previously labelled as "doubtful study", and in this regard endovaginal ultrasounds were useful to clarify diagnostic doubts. On the other hand, two patients with an obvious internal sphincter tear on anal endosonography were erroneously classified as normal on the vaginal study.

\section{DISCUSSION}

The coming of anal endosonography to the study of fecal incontinence has probably been the most important 


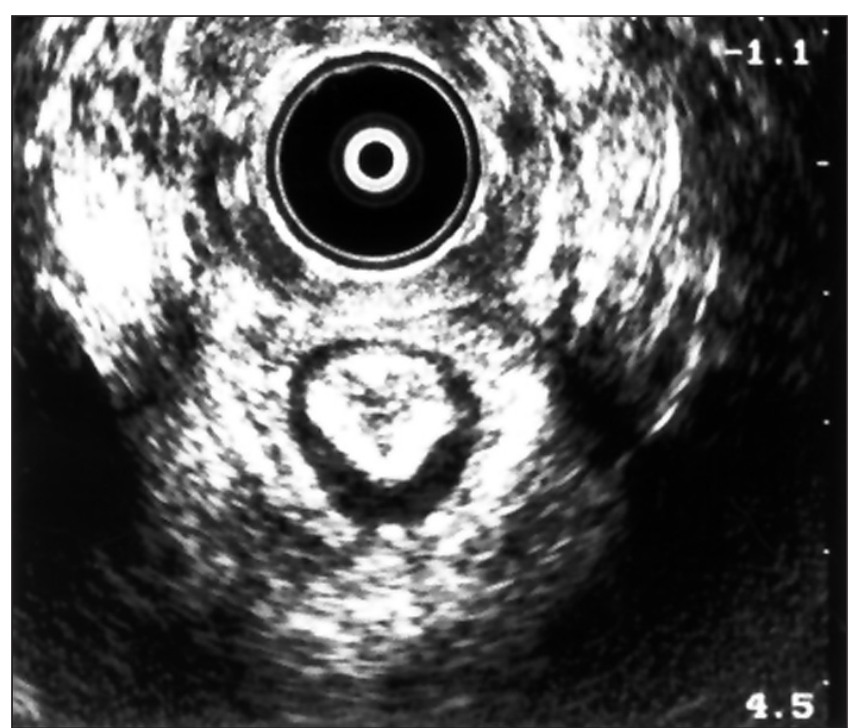

Fig. 3.- Endovaginal ultrasound in the same patient depicted in figure 2. In this scan the anal canal is normal, thus clarifying doubts arisen during the endoanal study.

Ecografía endovaginal en misma paciente de figura 2. Se aprecia claramente la integridad del canal anal, despejando las dudas del estudio endoanal.

improvement in the management of these patients during the last decades. It is of most importance for selecting a treatment option, and establishing the actual situation of the anal canal sphincter, not only by the recognition of a muscle tear but also by identifying the location and amount of tissue involved (9). In this regard, anal endosonography, a cheap, easy-to-perform and well-tolerated examination, is very useful (10).

Moreover, in well trained hands, endoanal ultrasound reports a high diagnosis accuracy improving the effectiveness of more traditional methods (11). Nevertheless, we share the opinion of those who believe that a weakness of this technique is the imaging of the anterior wall of the female anal canal. Women complaining of fecal incontinence often have a short anal canal, a wide perineum or a loose pelvic floor, variations which hinder the identification of the anal canal anatomy (6). For that reason it has been suggested that the anal probe be used through the vagina in addition to endoanal examinations in order to picture a less distorted anatomy from a different viewpoint $(7,8)$.

Indeed, vaginal endosonography allows to image the anal canal with no disturbance, thus making it possible to view the mucosal and submucosal tissue of the hemorrhoidal cushions as well as a thicker internal anal sphincter (Fig. 1). However, the worth of endovaginal ultrasound has not been established yet. For some authors its use -as well as the use of anal endosonographyis essential in the fecal incontinent woman (8), whilst other authors think its use remains uncertain (12).

As previously reported $(8,12)$ we also found it hard to obtain suitable images from the anal canal by vaginal endosonography due basically to a lack of good acoustic con- tact within the vagina. In fact, we were unable to perform and adequate examination in $7(23 \%)$ cases. Moreover, endovaginal ultrasound was of little precision in locating lateral tears. Although the internal anal sphincter is usually shown as a clear and thick black ring, in our hands transvaginal ultrasound was unable to detect 2 out of 3 defects imaged by anal ultrasound. This could be related to a lack of anal distension, with the fibers of this thin muscle remaining relaxed and thus overlapping and hiding the defect.

Apart from this, transvaginal ultrasound was of help in 3 patients (10\%). In two cases it served to clarify doubts arisen during endoanal ultrasound concerning the anterior wall; in the other case no anterior defect could be diagnosed by anal ultrasound (Table I).

In summary, transvaginal ultrasound is a difficult-toperform technique that has a high rate of failures when scrutinizing the anal canal. One in 4 patients cannot be properly explored by transvaginal ultrasound and, as a result, this technique cannot replace endoanal ultrasound, which remains the gold standard method for fecal incontinence. However, resulting from the fact that vaginal ultrasound adds little cost and no more than fifteen minutes to an anal examination -and the best diagnosis possible is of most importance for treatment planning-it is our opinion that endovaginal ultrasound should be considered an option for women when doubts exist about the integrity of the anterior anal canal.

\section{REFERENCES}

1. Ramírez JM, Mortensen NJMcM, Takeuchi N, Smilgin-Humphreys MM. Endoluminal ultrasonography in the follow-up of patients with rectal cancer. Br J Surg 1994; 81: 692-4.

2. Palacios Fanlo MJ, Ramírez Rodríguez JM, Aguilella Diago V, Arribas del Amo D, Martínez Diez M, Lozano Mantecon R. Ecografia endorrectal en los tumores de recto: eficacia, causas de error y limitaciones. Rev Esp Enferm Dig 2000; 92: 222-6.

3. Ramírez Rodríguez JM, Mortensen NJMcM, Smilgin-Humphreys MM. La endoecografía anal en el estudio de la incontinencia fecal. Rev Esp Enferm Dig 1995; 87: 211-5.

4. Bartram C, Buchanan G. Imaging anal fistula. Radiol Clin North Am 2003; 41: 443-57.

5. Kouraklis G, Andromanakos N. Evaluating patients with anorectal incontinence. Surg Today 2004; 34: 304-12.

6. Eckardt VF, Jung B, Fischer B, Lierse W. Anal endosonography in healthy subjects and patients with idiopathic faecal incontinence. Dis Colon Rectum 1994; 37: 235-42.

7. Sultan AH, Loder PB, Bartram CI, Kamm MA, HudSon CN. Vaginal endosonography. New approach to image the undisturbed anal sphincter. Dis Colon Rectum 1994; 37: 1296-9.

8. Poen AC, Felt-Bersma RJF, Cuesta MA, Meuwissen SGM. Vaginal endosonography of the anal sphincter complex is important in the diagnosis of faecal incontinence and perianal sepsis. Br J Surg 1998; 85: 359-63.

9. Kumar A, Rao SS. Diagnostic testing in fecal incontinence. Curr Gastroenterol Rep 2003; 5: 406-13.

10. Fuchsjager MH, Maier AG. Imaging fecal incontinence. Eur J Radiol 2003; 47: 108-16.

11. Rottenberg GT, Williams AB. Endoanal ultrasound. Br J Radiol 2002;75: 482-8.

12. Frudinger A, Bartram CI, Kamm MA. Transvaginal versus anal endosonography for detecting damage to the anal sphincter. AJR Am J Roentgenol 1997; 168: 1435-8. 